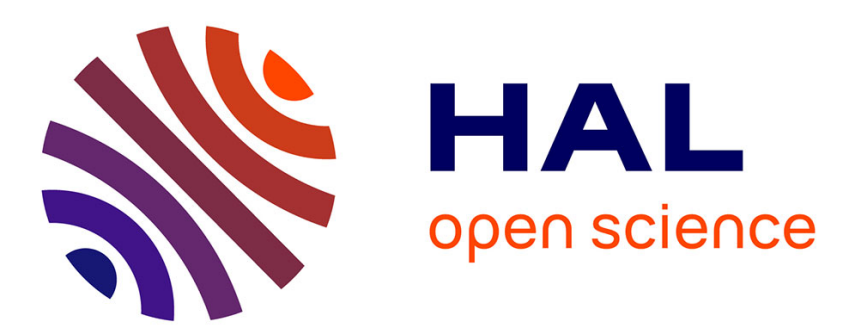

\title{
Book Review: Motivating Science. Science Communication from a Philosophical, Educational and Cultural Perspective
}

Justin Dillon

\section{- To cite this version:}

Justin Dillon. Book Review: Motivating Science. Science Communication from a Philosophical, Educational and Cultural Perspective. Public Understanding of Science, 2007, 16 (1), pp.113-115. 10.1177/096366250701600110 . hal-00571125

\section{HAL Id: hal-00571125 \\ https://hal.science/hal-00571125}

Submitted on 1 Mar 2011

HAL is a multi-disciplinary open access archive for the deposit and dissemination of scientific research documents, whether they are published or not. The documents may come from teaching and research institutions in France or abroad, or from public or private research centers.
L'archive ouverte pluridisciplinaire HAL, est destinée au dépôt et à la diffusion de documents scientifiques de niveau recherche, publiés ou non, émanant des établissements d'enseignement et de recherche français ou étrangers, des laboratoires publics ou privés. 
and cooling of spaces is the largest at 41 percent of this total. Adjusting heating habits, installing more efficient lighting and switching off all appliances after use provide readers with considerable options for reducing overall greenhouse gas emissions in the home.

Continuing through the book, other lifestyle impacts covered include food (particularly production and transportation), backyards (with a focus on waste and recycling) and work environments. All outline the main greenhouse gas contributors and offer the reader a variety of options for reducing emissions. The chapter detailing the financial burden of climate change is enlightening. Reay suggests that every tonne of greenhouse gas emitted costs an estimated US $\$ 40$ through damage caused. With an average family producing 39 tonnes per year, costs quickly mount. At present it is only those affected who are shouldering this financial burden, but with increasing talk of green taxes and emission quotas, individual accountability is becoming a distinct possibility. Convincing people that environmental taxation is the way forward is a little trickier, and herein lies the problem.

On the individual level it appears a lot can be done to help save the planet. We are all aware of the need to recycle, drive cars a little less and replace light bulbs with energy efficient ones. Where this book fills a niche, however, is with the lesser known facts and figures. Who knew, for example, that the average western family's Christmas contributes over half a tonne of greenhouse gases or that burials in the USA generate over 1.5 million tonnes of emissions per year? Since the more obscure climate impacts and mitigation options are addressed, even the most climate-savvy person is bound to learn a thing or two. Above and beyond a simple "how-to" guide Reay also digs a little deeper by acknowledging not only our impact on a changing climate but also a changing climate's impact on us.

Although we are made all too aware of the impact human actions have on the natural world, the impacts we face from these actions have only recently become salient. Recent extreme weather events, for example, are producing a torrent of health-related issues including thermal stress, with higher mortality rates for elderly populations and increased incidence of malaria and other infectious diseases (McMichael, Woodruff and Hales, 2006). Even within the home, our daily activities are shaped by the changing climate. Whether it is turning up the air conditioning during summer or switching on the heating two weeks later in winter, life in this global warming era is clearly a two-way street.
Despite Reay painting a compelling picture in the fight to combat climate change, I cannot help but clutch my pragmatist's hat. We are certainly living in an era of environmental awareness and opinion polls increasingly demonstrate this. Individuals however are particularly adept at thinking one thing yet doing another. How pragmatic then are the suggestions presented in this book? Although clearly thought out and meticulously researched, consideration of the likelihood of changing behaviour is insufficiently addressed. Collectively, it may be possible to change the path of the climate change glacier, as Reay suggests; but how this is done in practice is a different question altogether.

\section{Reference}

McMichael, A.J., Woodruff, R.E. and Hales, S. (2006) Climate change and human health: present and future risks, Lancet, 367, 859-69.

\section{Nicholas W. Smith}

Department of Psychology, University College London, UK

Nigel Sanitt (ed.), Motivating Science. Science Communication from a Philosophical, Educational and Cultural Perspective (Luton: Pantaneto Press, 2005). 243pp. ISBN 0954978005, $£ 13.95$ (pbk).

Motivating Science is a selection of articles published in the Pantaneto Forum (http://www. pantaneto.co.uk/), a quarterly e-journal which, "aims to promote debate on how scientists communicate, with particular emphasis on how such communication can be improved through education and a better philosophical understanding of science". Not surprisingly, 14 of the 26 articles have been published elsewhere or are based on talks given several years ago. The book has been put together by Nigel Sanitt, Pantaneto Forum's editor.

There is a danger, when putting together an edited collection spanning a broad range of topics, that the end result is a dog's breakfast. Sadly, this collection falls into this category. Part 1 of the book, "Media Issues", opens well, with the UK's Astronomer Royal, Martin Rees, addressing the issue of "Science, communication and the media". Rees notes that the phrase "public understanding of science" has "unfortunate connotations" and argues for a general understanding of science (GUST). Rees also argues that scientists should engage with social scientists about "the nature of the scientific enterprise, emphasizing that ... the outcome of scientists' 
efforts is a body of ideas that is 'objective' ...". UK readers of PUS will no doubt be looking forward to the opportunities to engage in such discussions afforded by Lord Rees' reign as President of the Royal Society. Bienvenido León's longer contribution, "Science communication techniques in television documentaries", examines the work of Sir David Attenborough. Based on interviews with Attenborough, León looks at how he reaches a balance between scientific rigour and journalistic interest, and examines issues including anthropomorphism, storytelling and argumentation.

Jenni Metcalfe and Toss Gascoigne's contribution is a seven-page advertisement for their media training workshops, and the chapter is heavily based on journalists' and scientists' evaluations of the two-day workshops. Metcalfe and Gascoigne conclude that scientists and journalists "are mutually suspicious of each other", though workshops can help to increase levels of trust. The commercial break over, the fourth contribution, "Socratic dialogue as a new means of participatory technology", from Beate Littig, is a description of a proposed two-year research project that was due to begin in January 2002. I can see no reason why this research proposal was published in this form in 2005 .

Carme Del Puento looks at the way that the Spanish media reported the discovery of the first candidate for a black hole in "From press release to headline". The chapter makes some interesting points but ends abruptly in mid-paragraph. Wolgang Goede's, "The view from the Rhine" is a short essay arguing the need for more science writers in Germany. A Portuguese contributor, António Fernando Cascais provides an insight into 'The rhetoric of breakthroughs in the communication of science'. Cascais concludes "What we understand by rhetoric of breakthroughs must be seen as an effect of censorship due to an illiteracy naturally segregated by techno scientific dynamics". I have no idea what this means. The chapter, which contains an introduction to Greek ideas of logos, ethos and pathos, surely deserves a better translation than the one afforded it here.

Parts of Roald Hoffmann's article, "Science, language and poetry" (which opens Part 2, "Language Processes"), were first published in 1988. Hoffmann's point is that "the language of science is inherently poetic", struggling, as it does, to describe the indescribable. Returning to the theme of rhetoric, Marcello Di Bari and Daniele Gouthier examine "Tropes, science and communication". Tropes (metaphors, allegories and the like) are the tools of classic rhetoric and, as such, can be used to describe the indescribable - well, almost. Neil Ryder is also in rhetorical form in the functionally titled "Science and rhetoric" chapter. Ryder notes that when the Royal Society was in its infancy, a campaign was launched to ban the use of tropes in science. Fortunately, sense prevailed and tropes continue to serve scientists and science communicators well.

Aquiles Negrete's 'Fact via fiction stories that communicate science' is based on his doctoral thesis. Negrete reports his empirical study in which two groups of students were asked to read either a factual text or a fictional narrative; both texts contained the same scientific information. He concludes that science can be learned through stories as well as through more conventional texts. Magda Osman's chapter, "How rational is deception?" is a reasonably interesting look at the relationship between deception and rationality. All communication, argues Osman, has an element of deception - an important point for anyone who communicates science, in particular, to consider.

In opening Part 3, "Education Debates", Dominique Lecourt in, "Extracts from: 'The teaching of philosophy of science", bemoans the lack of philosophical training in the university education of scientists and makes a case for the creation of a French National Institute for Philosophy of Science. More pragmatically, Fouad Abd-El-Khalick, an educational researcher based in the USA, describes his doctoral study which involved explicitly (and successfully) teaching undergraduates about the history and philosophy of science. Continuing the theme, Herbert Pietschmann describes how the University of Vienna's theoretical physics course was split into two streams, one for potential research scientists and the other for potential physics teachers. After a reasoned beginning, the chapter, "How to teach physics in an anti-scientific society" deteriorates as the author, a physicist, ventures into educational territory. In rather the same vein, Harvard physics professor Eric Mazur asks "Are we teaching the right thing?" and (shakes head at lack of students' understanding of basic scientific concepts) concludes "no". Determined to do something about her unreflective engineering undergraduates, Australian academic Patricia Kelly and a colleague introduced reflective writing and other activities into their courses; it worked. Another Australian academic, James Franklin, describes how the University of New South Wales made every undergraduate take a course on "Professional Issues and Ethics" during their degree programme. Franklin describes how he turned this blanket approach into something engaging and creative. Finally, in this part, David Carr gets deeply involved in answering the question "Is teaching a skill?". After ten pages of 
moral dimensions, Aristotle and pedagogical virtues, Carr concludes that "the really deep professional challenges of education and teaching are implicated in a web of complex intellectual, moral and normative questions ...". Indeed.

Part 4, "Philosophical Bridges", opens with a long piece by Catharine Stimpson entitled, "Creative co-dependents: Science, the arts and the humanities". Stimpson's point is that those three great pillars of wisdom are co-dependent and we are impoverished because we do not recognize that fact. Stimpson's chapter, though long, is quite thoughtful and contains the best anecdote of the whole book: a story told by Robert Weisbuch when he was interim graduate dean at the University of Michigan. If you are a humanities scholar, you should refrain from reading it. Humanities scholars get no respite from another US academic, Deborah Lines Andersen, who compares different academic groups in terms of their work patterns and behaviors. I found this an interesting and thoughtful chapter and one of the few that left me wanting more not less. Speaking of wanting less, Mordechai Ben-Ari's chapter, "Why was there only one Japan?" is a critique of Jared Diamond's book, Guns, Germs and Steel. I cannot comprehend why this chapter is in a book on science communication. Next up, Roger Trigg, a professor of philosophy at the University of Warwick, argues for the value of philosophy. Again, it is on the very border of what might be expected to be in a book about science communication. The same might be said for Martin Pitt's chapter, "Should we believe in the Loch Ness Monster?", where he details how his opinion about the existence of the Loch Ness Monster changed with time, experience and the lack of any actual monster. Pitt concludes, in tones usually reserved for judges delivering death sentences, that "the Loch Ness Monster does not and did not ever exist". Pitt's point is that thinking about how his view has changed has made him more critical and reflective of his other beliefs.

Having struggled through Socratic Dialogue in Part 1, I was surprised that it raises its head again in Part 4. Stan Van Hooft provides a clear description of how the technique might be used to answer the question "What is Human Dignity?". The technique might offer something for science communicators organizing public engagement debates on topics such as xenotransplantation. One wonders why, then, is this chapter so far from Beate Littig's earlier chapter? Finally, Friedel Weinert examines "Einstein as philosopher" showing how, at times when science becomes shaky, "the physicist is forced to become a philosopher". Einstein, Weinert points out, noted that "science without philosophy is a muddle, and philosophy without science is an empty space".

There are many editorial inconsistencies in Motivating Science - in the amount of biographical detail accorded to each author, and in the referencing, for example. There are some interesting articles which I have indicated above. But they are already available on the Pantaneto Forum website, for free. Anyone who buys the book should ask themselves "why am I doing this?".

\author{
Justin Dillon \\ Centre for Informal Learning and Schools, \\ King's College London, London, UK
}

